\title{
Dependence of the leopard Panthera pardus fusca in Jaipur, India, on domestic animals
}

\author{
Swapnil Kumbhojkar, Reuven Yosef, Jakub Z. Kosicki \\ Patrycja K. KWIATKOWSKa and Piotr Tryjanowsi
}

\begin{abstract}
The ecology and predator-prey dynamics of large felids in the tropics have largely been studied in natural systems where wild ungulates constitute the majority of the prey base. However, in tropical countries where communities are primarily agrarian, the high density of domestic animals in human-dominated landscapes can be a potential prey source for large carnivores. We demonstrate almost complete dependence of the Vulnerable leopard Panthera pardus fusca in the Jhalana Reserve Forest in Jaipur, northwest India on domestic animals as prey. We analysed 132 leopard scats collected during the dry season of November 2017-April 2018. Domestic animals comprised the majority of the leopards' prey (89.5\% frequency of occurrence): dogs Canis lupus familiaris (44\%), cats Felis catus (13\%), goats Capra aegagrus hircus (16\%) and cattle Bos taurus (15\%). Wild species, which occurred in the leopards' diet at a relatively low frequency, were rodents, the hare Lepus nigricollis, small Indian civet Viverricula indica, rhesus macaque Macaca mulatta, northern plains grey langur Semnopithecus entellus and mongoose Herpestes edwardsii. Diet is also a function of availability of potential prey, but no data are available on the density of the leopard's wild prey species in Jhalana Reserve Forest. Nevertheless, our results suggest that abundance of domestic prey around Jhalana Reserve Forest sustains the c. 25 known leopards. We conclude that these leopards, by preying on feral dogs in an urban environment, could be considered as suppliers of a service to the human population amongst whom they thrive, although this potentially exposes the leopards to the canine distemper virus.
\end{abstract}

Keywords Diet, environmental service, human-dominated landscape, India, Jhalana, leopard, Panthera pardus fusca

SwapNIL KumbHoJKar Jhalana Wildlife Research Foundation, Pune, India

ReUven YoseF (Corresponding author, (D) orcid.org/0000-0003-4331-9866) Ben Gurion University of the Negev-Eilat Campus, P. O. Box 272, 88106 Eilat, Israel E-mail ryosef60@gmail.com

JAKUB Z. Kosicki Department of Avian Biology \& Ecology, Faculty of Biology, Adam Mickiewicz University, Poznań, Poland

Patrycja K. Kwiatkowska Institute of Zoology, Poznań University of Life Sciences, Poznań, Poland

Piotr Tryjanowski Faculty of Environmental Sciences, Czech University of Life Sciences Prague, Prague, Czech Republic

Received 7 June 2019. Revision requested 15 July 2019.

Accepted 3 September 2019. First published online 2 October 2020.

\section{Introduction}

Towledge of prey selection and diet is important for Lunderstanding the life history strategies of carnivores and for planning the conservation of an apex predator (Miquelle et al., 1996). The density of carnivores is related to habitat quality, in particular to the availability of prey (Fuller \& Sievert, 2001; Carbone \& Gittleman, 2002; Andheria et al., 2007; Karanth \& Nichols, 2010). To enhance the cost-benefit ratio of energetic intake, large carnivores may visit areas close to, or even inside, human settlements (Gehrt et al., 2010; Yirga et al., 2012; Athreya et al., 2013). Fear of carnivores, especially in the context of livestock depredation, can negatively affect people's well-being (Inskip \& Zimmermann, 2009). It has been shown that the abundance and availability of wild and domestic prey is the predominant factor that determines the potential carrying capacity of human-dominated landscapes for large carnivores (Boitani \& Powell, 2012). In human-dominated landscapes in Brazil, Nepal and Kenya (Schaller, 1983; Seidensticker et al., 1990; Mizutani, 1999) the biomass of potential domestic prey of carnivores was higher than that of wild prey species. Discarded food waste and pet food may also contribute to the food resources of carnivores (Gehrt et al., 2010). This reduces carnivores' fear of humans and, in consequence, the density of carnivores in urban or semi-urban areas can be higher than in the wild (Butler et al., 2014).

In India, the intrusion of large predators into urban areas is well documented. Wolves Canis lupus (Jhala \& Giles, 1991), Asiatic lions Panthera leo persica (Meena et al., 2011), striped hyaenas Hyaena hyaena (Singh et al., 2010) and tigers Panthera tigris (Karanth \& Gopal, 2005) are known to attack livestock and persist in humandominated landscapes. The leopard Panthera pardus fusca also lives successfully in the proximity of people (Athreya et al., 2004). Its broad diet includes amphibians, arthropods and carrion, reducing dependence on water sources, which is obtained from the prey (Daniel, 2009; Kshettry et al., 2018). Compared to larger felids, the small body size of the leopard reduces the territory required to sustain a population and allows it to survive and thrive in proximity to people (Daniel, 2009; Kshettry et al., 2018).

To examine resource utilization by leopards in a rural, semi-urban human-dominated landscape, we analysed the diet of leopards of the Jhalana Reserve Forest. Because the Reserve is in close proximity to and surrounded by human habitations, leopards have little fear of people and 


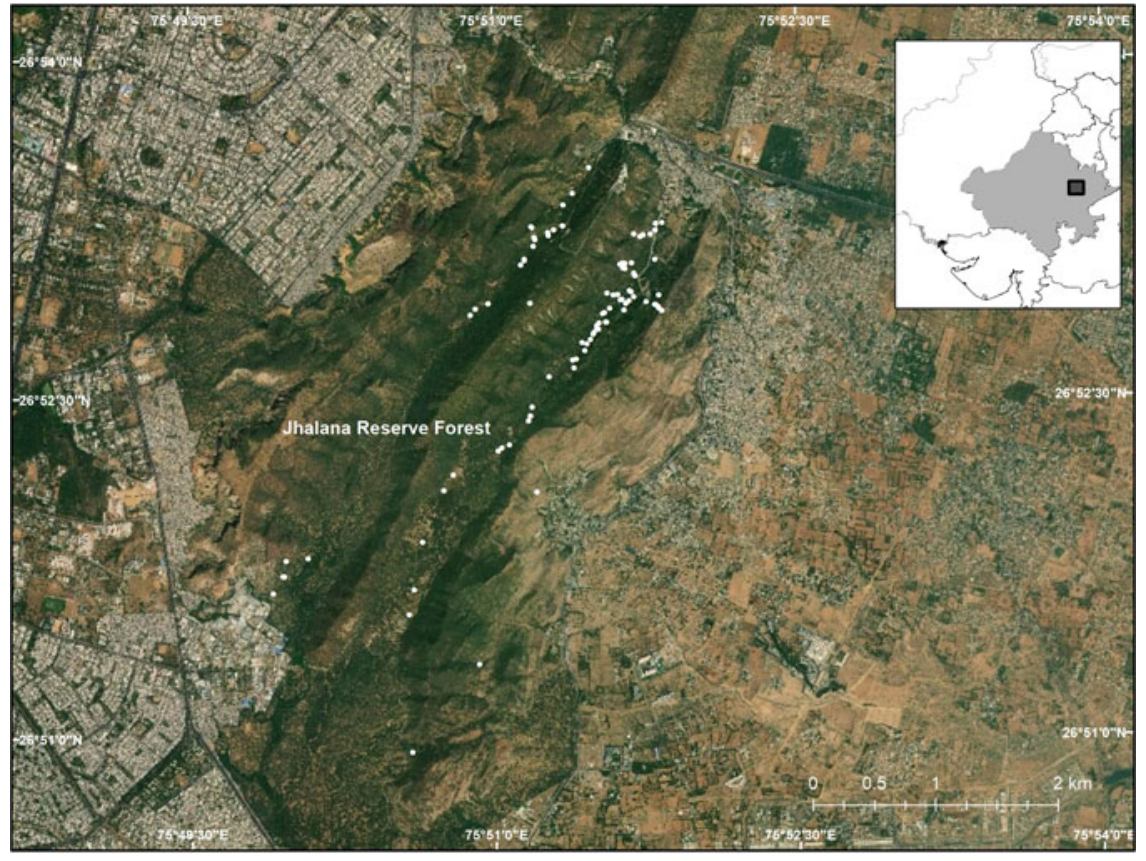

FIg. 1 Jhalana Reserve Forest in north-west India, and the surrounding city of Jaipur, with the locations of the leopard Panthera pardus fusca scats collected. often feed opportunistically on easily accessible domestic prey (Athreya et al., 2013, 2014). We thus hypothesized that the leopards' diet comprises principally of domestic animals. Our objectives were to identify the leopards' key prey species and examine their importance for humanleopard coexistence and acceptance of the presence of leopards in the urban landscape (Kumbhojkar et al., 2019).

\section{Study area}

The $29 \mathrm{~km}^{2}$ Jhalana Reserve Forest lies on the south-east border of the city of Jaipur in north-west India (Fig. 1). It was designated on 21 November 1961 in accordance with the provisions of Rajasthan Forest Act 1953. The Reserve has a mean altitude of $516 \mathrm{~m}$, with higher elevations in the north in the form of low, flat-topped hills, and is characterized by tropical dry deciduous forest. During the 1980 os the main valley was planted with the native species Acacia tortilis and Acacia senegal.

\section{Methods}

The population of leopards in the Reserve has been estimated, using camera traps and recognition of individuals, to comprise 25 individuals (authors, unpubl. data). In a 2017 survey of the Reserve we found that leopards used trails and tourist routes for defecation. We monitored the trails, collecting 138 scat samples in the dry season of November 2017-April 2018 (Kumbhojkar et al., 2019; Fig. 1).

The identity of leopard scats was confirmed using their occurrence in scrapes characteristic of those made by large felids (the leopard is the only large felid present in the Reserve). Trained volunteers wearing gloves used forceps to collect the scats. A small portion of each scat was left, so as to not disrupt the natural markings of the leopards (Schwarz \& Fischer, 2006). The location of each scat was noted, with a GPS, at the time of collection. Scats were stored in numbered polythene, zip-lock bags. Preliminary observations such as the presence of bones, claws, skin and other biological remains were noted if appropriate.

Highly degraded scats $(n=6 ; 4.3 \%)$ were excluded from the analysis and only well-preserved scats $(n=132)$ were analysed. They were washed under running water and sundried. The cuticular and medullar patterns of any hair remains were observed and photographed under a compound microscope. Scat analysis was based on Mukherjee et al. (1994), Mukherjee \& Mishra (2001), diet-related studies (Karanth \& Sunquist, 1995; Biswas \& Sankar, 2002; Sankar \& Johnsingh, 2002; Andheria et al., 2007; Khorozyan et al., 2008; Odden \& Wegge, 2009), and our own collections of prey remains. All hair, hooves, claws, teeth, nails and bones were separated for further analysis. Prey species were identified based on comparison with reference slides of hair samples from domestic animals in the study area and from reference slides of hair samples from wild prey and from previous studies (Oli, 1993; Tiwari, 2008).

To assess if the sample size was sufficient for accurate diet analysis (Edgaonkar \& Chellam, 1998; Kshettry et al., 2018) we applied the rarefaction method, implemented in EstimateS 9.1 (Colwell, 2005). This method estimates the expected cumulative number of species, with $95 \%$ confidence intervals (the Mao Tau estimator; Colwell, 2005). 


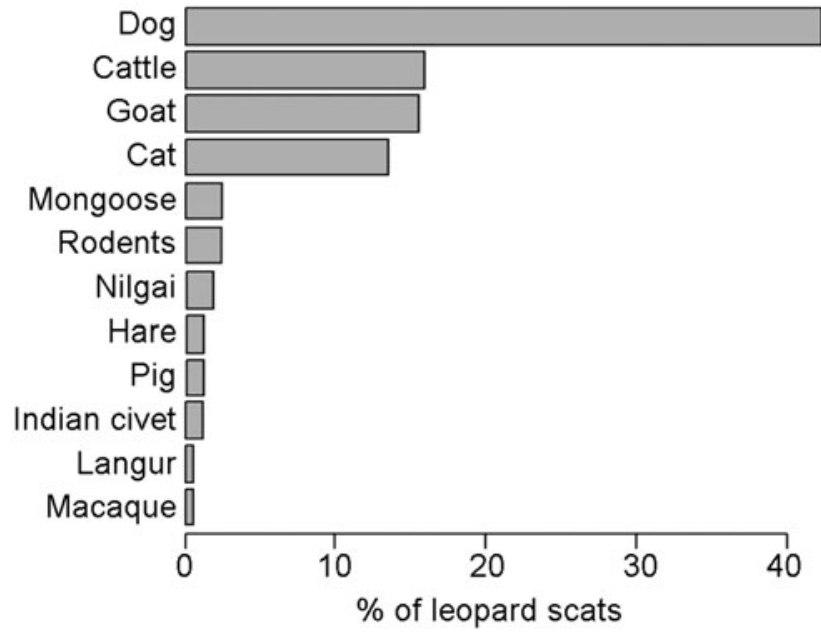

FIG. 2 Per cent of 132 leopard scats collected in Jhalana Reserve Forest (Fig. 1) that contained various prey species/taxa (Table 1).

We calculated the relative biomass of prey species consumed using the regression equation $Y=0.35 X+1.98 Y$, where $Y$ is the mass of prey consumed per scat and $X$ is the mean mass of the prey (cf. Ramesh et al., 2009). The regression equation is derived based on feeding trials with captive mountain lions Puma concolor (Ackerman et al., 1984) to calculate relative biomass based on their relative proportions in scats. As mountain lions and leopards are similar in size, this method has been used previously for leopards (Karanth \& Sunquist, 1995; Andheria et al., 2007; Khorozyan et al., 2008; Odden \& Wegge, 2009; Wegge et al., 2009; Athreya et al., 2014).

The frequencies of occurrence of prey species (the per cent of the total number of scats that contained a specific prey item) were calculated but, as smaller prey species may contribute more to scats than larger species (Karanth \& Sunquist, 1995; Klare et al., 2011), this variable may potentially be misleading. The relative biomass $(D)$ was therefore calculated using:

$$
D=\frac{A Y}{\sum A Y} \times 100
$$

where $A$ is the frequency of occurrence of the prey species. The relative per cent of each prey species consumed $(E)$ was obtained using:

$$
E=\frac{\frac{D}{X}}{\sum \frac{D}{X}} \times 100
$$

Because we found that the correlations between $Y, D$, and $E\left(R^{2}\right.$ 0.28-0.99) were all significant at $\mathrm{P}<0.01$, we only tested differences in biomass $(D)$ between domestic and wild prey species by $\mathrm{t}$ test with Cochran-Cox adjustment

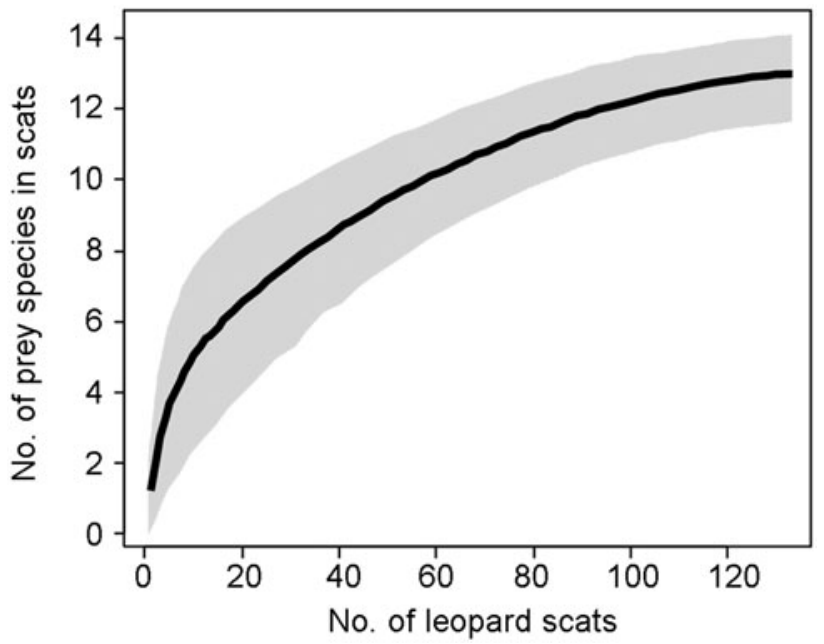

FIG. 3 Cumulative number of prey species in leopard scats (solid line), with $95 \%$ confidence interval (shaded area).

(Zar, 1996). All calculations were conducted in $R$ 3.6.o (R Core Team, 2013).

\section{Results}

The 132 scats had a mean of 9.8 \pm SE 0.24 (9.3-10.3 95\% CI) prey species. Most of the scats $(108 ; 82 \%)$ were found alongside trails or jeep tracks. Of the 2,640 hairs selected from scats, $158(6 \%)$ were unidentified. The scats contained a total of 12 prey taxa: 11 individual species and rodents, which were not identified to species level (Fig. 2). Seventy-nine per cent (105) of the scats contained only one prey species; $21 \%$ contained two or more species. The individual-based rarefaction curve shows that the increase in the cumulative number of species in scats was rapid for the first c. 8 o scats but began to level off thereafter (Fig. 3). In the 132 leopard scats the majority (89.5\%) of prey frequency of occurrence comprised domestic animals (domestic dogs Canis lupus familiaris, 44\%; domestic cats Felis catus, 13\%; goats Capra aegagrus hircus, 16\%; cattle Bos taurus, $15 \%$ ) and wild prey comprised $11 \%$ of prey frequency of occurrence; the difference was significant ( $G$ test; $G=4.16$, $\mathrm{P}<0.001$ ). The mean biomass of domestic animal species detected in the scats was 1.29 and that of wild prey was 0.02 $\mathrm{kg}$; the difference was significant $(t=2.78, \mathrm{P}=0.038$; Table 1$)$.

\section{Discussion}

In urban landscapes the relationship between large felids and humans is complex, influenced by people's fear and awe (Boomgaard, 2001; Loveridge et al., 2010). Aversion occurs when the presence of a large felid results in damage to property or loss of human life (Treves et al., 2006), with retaliatory killings resulting in significant felid mortality 
TABLE 1 Mean weight, per cent frequency, mass consumed per scat, relative biomass consumed and relative per cent of prey, in decreasing order of frequency, for each of the 12 prey taxa recorded in the 132 scat samples of the leopard Panthera pardus fusca.

\begin{tabular}{|c|c|c|c|c|c|}
\hline Taxon & Weight ${ }^{1}(\mathrm{~kg})$ & Frequency (\%) & $Y^{2}(\mathrm{~kg})$ & $D^{2}(\mathrm{~kg})$ & $E^{2}(\%)$ \\
\hline Domestic dog Canis lupus familiaris & 18.00 & 44.0 & 8.28 & 2.96 & 37.16 \\
\hline Domestic goat Capra aegagrus hircus & 25.00 & 16.0 & 10.73 & 1.50 & 18.82 \\
\hline Domestic cattle (calf) Bos taurus & 40.00 & 15.0 & 15.98 & 2.14 & 26.93 \\
\hline Domestic cat Felis catus & 2.00 & 13.0 & 2.68 & 0.30 & 3.84 \\
\hline Indian grey mongoose Herpestes edwardsii & 2.00 & 3.0 & 2.68 & 0.05 & 0.69 \\
\hline Rodents (Rodentia) & 0.10 & 3.0 & 2.01 & 0.05 & 0.63 \\
\hline Nilgai Boselaphus tragocamelus & 140.00 & 2.2 & 50.98 & 0.76 & 9.64 \\
\hline Hare Lepus nigricollis & 2.10 & 1.5 & 2.71 & 0.02 & 0.35 \\
\hline Domestic pig Sus scrofa domesticus & 21.00 & 1.5 & 9.33 & 0.09 & 1.20 \\
\hline Indian civet Viverricula indica & 0.08 & 1.5 & 2.01 & 0.02 & 0.25 \\
\hline Langur Semnopithecus entellus & 8.00 & 0.7 & 4.78 & 0.02 & 0.28 \\
\hline Rhesus macaque Macaca mulatta & 7.00 & 0.7 & 4.43 & 0.02 & 0.25 \\
\hline
\end{tabular}

${ }^{1}$ From Karanth \& Sunquist (1995), Biswas \& Sankar (2002), Sankar \& Johnsingh (2002) and Andheria et al. (2007).

${ }^{2} Y$, mass of prey consumed per scat; $D$, relative biomass; $E$, relative per cent of each prey species consumed (see text for further details).

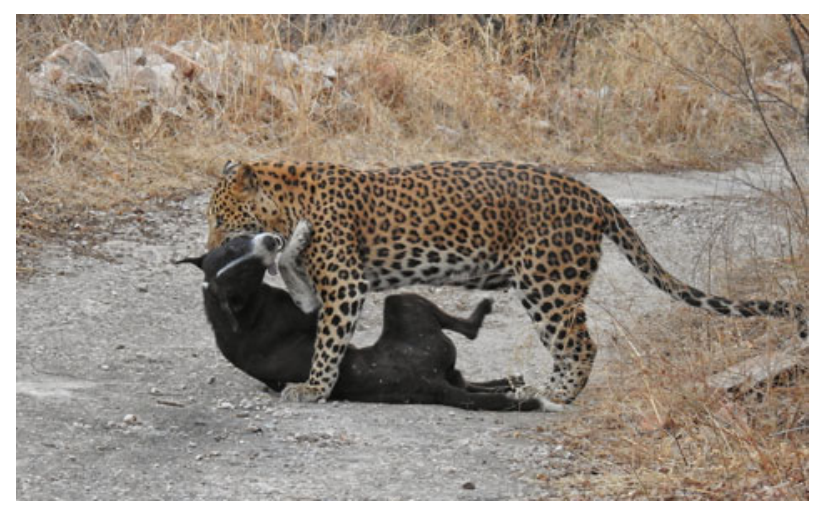

Plate 1 Leopard Panthera pardus fusca preying on a domestic dog that strayed into the boundaries of Jhalana Reserve Forest. Photo: Devam Shah.

(Inskip \& Zimmermann, 2009). Studies have therefore focused on so-called human-felid conflict (Inskip \& Zimmermann, 2009). Dependence of felids on domestic livestock has rarely been observed, however; domestic livestock usually contribute only a small proportion of the biomass consumed by felids (Athreya et al., 2014). In urban landscapes the biomass of domestic animals is usually high and usually exceeds that of wild prey in the neighbouring forests (Schaller, 1983). So, if domestic animals lack antipredatory behaviour, they are more susceptible to attacks (Diamond, 2002). Jhalana Reserve Forest is surrounded by urban and rural areas with c. 4 million inhabitants (World Population Review, 2020). People living in the surrounding neighbourhoods and villages practice traditional livelihood professions such as livestock farming. Goats and the calves of cattle are available as leopard prey along with domestic dogs, cats and pigs. An estimated population of 36,580 domestic dogs was documented in a 2011 survey in Jaipur (Hiby et al., 2011). This is a sizeable source of potential prey for the leopards. Hence, it is unsurprising that leopards move between the protected area and human habitat, despite the $5 \mathrm{~m}$ high barrier built around Jhalana to separate it from the city of Jaipur (Fig. 1). There are no data available on the densities or numbers of the leopards' wild prey species in Jhalana Reserve Forest. There are, however, data on the vaccination and sterilization of feral domestic dogs undertaken for the past 2 decades by the Help in Suffering Foundation, Jaipur (J. Reece, pers comm., 2019): a mean of c. 7,500 rabies inoculations were conducted annually over the past 21 years, to protect residents in the case of bites from feral dogs. Previous studies have shown that the availability of a large number of domestic animals in rural and urban areas facilitates the survival of leopards near human habitats (Athreya et al., 2004; Kshettry et al., 2018). Persistence of leopard populations in human-dominated habitats beyond protected areas is dependent on a stable and abundant domestic prey base (Athreya et al., 2013).

The Mao Tau diversity estimator indicated that 90-100 scat samples sufficed to give a representative sample of the species included in the diet of the leopards (Fig. 3). Biswas \& Sankar (2002) considered that a minimum of 60 scats needed to be analysed to examine the prey base of tigers.

Scat analysis substantiated our hypothesis that the predominant prey of leopards in Jhalana Reserve Forest are domestic animals, presumably from the neighbouring city and villages. Our results corroborate the results of Daniel (2009) and demonstrate that dogs are a major food resource for leopards in the Reserve (Plate 1). Scat analysis from the states of Maharashtra and Jammu and Kashmir have also reported the importance of dogs as prey for leopards (Edgaonkar \& Chellam, 2002; Shah et al., 2009). In West Bengal, however, livestock (cattle and goats; 48\%) predominated in the diet of leopards (Kshettry et al., 2018), whereas cattle and goats comprised $31 \%$ of the diet in Jhalana Reserve Forest. In Ayubia 
National Park, Pakistan, the leopard similarly subsisted mainly on domestic animals, with goats predominating (64.9\%) the frequency of occurrence (Shehzad et al., 2015).

The differences between our results and other studies are a consequence of the high number of dogs and cats in our study area. The total dog and cat populations in the area are estimated to be c. 32,500 and 7,500 individuals, respectively (J. Reece, pers. comm., 2019); these species are thus widely available. Cattle and goats are relatively less abundant $(31 \%)$ because these animals are herded during the day and protected in enclosures at night. Similarly, in Sanjay Gandhi National Park, Mumbai, leopards have adapted to the depleted wild ungulate prey base by feeding on dogs found in the surrounding areas and by scavenging on buffalo carcasses (Edgaonkar \& Chellam, 2002).

In spite of the higher frequency of goats in the leopard scats we analysed, the relative biomass of cattle was higher, a result of the greater weight of cattle. A similar finding was made in the study of leopard diet in Sri Lanka (Mukenhirn \& Eisenberg, 1973). In our study the leopards were probably feeding on discarded carcasses of calves as the Rajasthan Forest Department does not have any records of claims for compensation for predation of cattle.

The fact that leopards prey on the most easily available species (the most numerous), has already been demonstrated (Schaller, 1967; Seidensticker, 1983; Kshettry et al. 2018). With a diet dominated by domestic dogs and cats rather than by domestic livestock, the potential economic impact of the leopards of Jhalana Reserve Forest is lower compared to areas where predation of livestock is high and there is a consequent lack of tolerance for such damage (cf. Margulies \& Karanth, 2018). In addition a large proportion of the rural population surrounding Jhalana Reserve Forest are Jains, who practise the conservation of biodiversity, and especially of large felids (Athreya et al., 2018); this facilitates human-leopard coexistence (Kumbhojkar et al., 2019).

Domestic dogs are a public health problem in India and elsewhere (Reece \& Chawla, 2006) and occasionally attack other small domestic animals (Srinivasan, 2013). For people, dog bites can result in infection, disfigurement, incapacity, post-traumatic stress, and even death, and bites from infected dogs account for $>90 \%$ of rabies cases (Seligsohn, 2014; Taylor et al., 2017). Only $2 \%$ of the total dog population in the study area are vaccinated (J. Reece, pers. comm., 2019; Reece \& Chawla 2006). Dogs could also transfer infectious diseases to leopards. Canine distemper virus is the second most common cause of death in domestic dogs (Deem et al., 2000) and is also responsible for disease outbreaks amongst the African lion Panthera leo in the Serengeti, the Amur tiger Panthera tigris altaica in the Russian Far East and the Asiatic lion in India (Roelke-Parker et al., 1996; Seimon et al., 2013; ICMR, 2018). Leopards that prey substantially on domestic dogs, as do those of Jhalana Reserve Forest, could be considered as suppliers of a service to the human population amongst whom they thrive, although this potentially exposes the leopards to the canine distemper virus.

Acknowledgements We thank Sudharshan Sharma, Deputy Conservator of Forests, for his guidance, the Rajasthan Forest Department for permission to conduct research on the leopards of Jhalana and for collecting scat and biological samples; Pratiksha Vedpathak, Benazir Bagwan, Aseem Shendye and Abhay Shendye from Swasti Agro and Bio-Products Pvt. Ltd. for technical support and assistance with scat analysis; Satish Pande, Satish Karmalkar, Pramod Deshpande, Sanjay Khatavkar and Rajkumar Pawar of Ela Foundation for provision of equipment and laboratory facilities for scat analysis; Rahul Lonkar; Bablu Gurjar, Abhishek Gurjar, Dayal Gurjar, Shubham Saini, Varad Bansod and Hrishikesh Wagh for help with field surveys, scat collection and washing of the scats; G.V. Reddy, Head of Forest Office, Rajasthan Forest Department arranged training at Sanjay Gandhi National Park, Mumbai, for scat analysis; Vidhya Athreya, Nikit Surve and his team of volunteers for training in the field; and Abhinav Mehta for drafting Fig. 1.

Author contributions Study design, fieldwork: SK, RY; data analyses, writing: all authors.

\section{Conflicts of interest None.}

Ethical standards This research do not involve handling of animals and otherwise abided by the Oryx guidelines on ethical standards. SK and RY worked under research permit 171 of the Rajasthan Forest Department.

\section{References}

Ackerman, B.B., Lindzey, F.G. \& Hemker, T.P. (1984) Cougar food habits in southern Utah. Wildlife Magazine, 48, 147-155.

Andheria, A.P., Karanth, K.U. \& Kumar, N.S. (2007) Diet and prey profiles of three sympatric large carnivores in Bandipur Tiger Reserve, India. Journal of Zoology, 273, 169-175.

Athreya, V.R., Thakur, S.S., Chaudhuri, S. \& Belsare, A.V. (2004) Leopards in human-dominated areas: a spillover from sustained translocations into nearby forests. Journal of Bombay Natural History Society, 104, 45-50.

Athreya, V.R., Thakur, S.S., Chaudhuri, S. \& Belsare, A.V. (2004) A Study of the Man-Leopard Conflict in the Junnar Forest Division, Pune District, Maharashtra. Submitted to the Office of the Chief Wildlife Warden, Maharashtra State Forest Department, and the Wildlife Protection Society of India, New Delhi, India. projectwaghoba.in/docs/junnar_conflict_report_athreya_et_2004_ condensed.pdf [accessed January 2020].

Athreya, V., Odden, M., Linnell, J.D.C., Krishnaswamy, J. \& KARANTH, K.U. (2013) Big cats in our backyards: persistence of large carnivores in a human dominated landscape in India. PLOS ONE, $8, \mathrm{e} 57872$

Athreya, V., Odden, M., Linnell, J.D.C., Krishnaswamy, J. \& Karanth, K.U. (2014) A cat among the dogs: leopard Panthera pardus diet in a human-dominated landscape in western Maharashtra, India. Oryx, 50, 156-162.

Athreya, V., Pimpal, S., Borkar, A.S., Surve, N., Chakravarty, S., Ghosalka, M. et al. (2018) Monsters or gods? Narratives of large cat worship in western India. CatNews, 67, 23-28.

Biswas, S. \& Sankar, K. (2002) Prey abundance and food habits of tigers (Panthera tigris tigris) in Pench National Park, Madhya Pradesh, India. Journal of Zoology, 256, 411-420. 
Boitani, L. \& Powell, R.A. (eds) (2012) Carnivore Ecology and Conservation: A Handbook of Techniques. Oxford University Press, New York, USA.

Boomgand, P. (2001) Frontiers of Fear: Tigers and People in the Malay World, 1600-1950. Yale University Press, New Haven, USA.

Butler, J.A., Linnell, J.C., Morrant, D., Athreya, V., Lexcureux N. \& McKeown, A. (2014) Dog eat dog, cat eat dog: social-ecological dimensions of dog predation by wild carnivores. In Free-Ranging Dogs and Wildlife Conservation (ed. M. Gompper), pp. 117-143, Oxford University Press, Oxford, UK.

Carbone, C. \& Gittleman, J.L. (2002) A common rule for the scaling of carnivore density. Science, 295, 2273-2276.

Colwell, R.K. (2005) EstimateS: Statistical Estimation of Species Richness and Shared Species from Samples. Version 7.5. purl.oclc.org/ estimates [accessed January 2020].

Daniel, J.C. (2009) The Leopard in India: A Natural History. Natraj Publishers, Dehradun, India.

Deem, S.L., Spelman, L.H., Yates, R.A. \& Montali, R.J. (200o) Canine distemper in terrestrial carnivores: a review. Journal of Zoo and Wildlife Medicine, 31, 441-451.

Diamond, J. (2002) Evolution, consequences and future of plant and animal domestication. Nature, 418, 700-707.

Edgaonkar, A. \& Chellam, R. (1998) A Preliminary Study on the Ecology of the Leopard, Panthera pardus fusca in the Sanjay Gandhi National Park, Maharashtra. Wildlife Institute of India, Dehra Dun, India.

Edgaonkar, A. \& Chellam, R. (2002) Food habit of the leopard, Panthera pardus, in the Sanjay Gandhi National Park, Maharashtra, India. Mammalia, 66, 353-360.

Fuller, T.K. \& Sievert, P.R. (2001) Carnivore demography and the consequences of changes in prey availability. In Carnivore Conservation (eds J.L. Gittleman, S.M. Funk, D.W. Macdonald \& R.K. Wayne), pp. 163-178. Cambridge University Press, Cambridge, UK.

Gehrt, S.D., Riley, S.P.D. \& Cypher, B.L. (eds) (2010) Urban Carnivores: Ecology, Conflict and Conservation. Johns Hopkins University Press, Baltimore, USA.

Hiby, L.R., Reece, J.F., Wright, R., Jaisinghani, R., Singh, B. \& Hiby, E.F. (2011) A mark resight survey method to estimate the roaming dog population in three cities in Rajasthan, India. $B M C$ Veterinary Research, 7, 46.

Inskip, C. \& ZimmermanN, A. (2009) Human-felid conflict: a review of patterns and priorities worldwide. Oryx, 43, 18-34.

Jhala, Y.V. \& Giles, R.H. (1991) The status and conservation of the wolf in Gujarat and Rajasthan, India. Conservation Biology, $5,476-483$.

Karanth, K.U. \& Gopal, R. (2005) An ecology-based policy framework for human-tiger coexistence in India. In People and Wildlife: Conflict or Coexistence? (eds R. Woodroffe, S. Thirgood \& A. Rabinowitz), pp. 373-387. Cambridge University Press, Cambridge, UK.

KarAnth, K.U. \& Nichols, J.D. (2010) Non-invasive survey methods for assessing tiger populations. In Tigers of the World: The Science, Politics and Conservation of Panthera tigris (eds R.L. Tilsonand \& P.J. Nyhus), pp. 241-262. Elsevier, New York, USA.

Karanth, K.U. \& Sunquist, M.E. (1995) Prey selection by tiger, leopard and dhole in tropical forests. Journal of Animal Ecology, 64, 439-450.

Khorozyan, I.G., Malkhasyan, A.G. \& Abramov, A.V. (2008) Presence-absence surveys of prey and their use in predicting leopard (Panthera pardus) densities: a case study from Armenia. Integrative Zoology, 3, 322-332.

Klare, U., Kamler, J.F. \& Macdonald, D.W. (2011) A comparison and critique of different scat-analysis methods for determining carnivore diet. Mammal Review, 41, 294-312.
Kshettry, A., Vaidyanathan, S. \& Athreya, V. (2018) Diet selection of leopards (Panthera pardus) in a human-use landscape in North-Eastern India. Tropical Conservation Science, 11, 1-9.

Kumbhojkar, S.V., Yosef, R., Benedetti, Y. \& Morelli, F. (2019) Human-leopard (Panthera pardus fusca) co-existence in Jhalana Reserve Forest, North India. Sustainability, 11, 3912.

Loveridge, A.J., Wand, S.W., Frank, L.G. \& Seidensticker, J. (2010) People and wild felids: conservation of cats and management of conflicts. In Biology and Conservation of Wild Felids (eds D.W. Macdonald \& A.J. Loveridge), pp. 161-198. Oxford University Press, Oxford, UK.

Margulies, J.D. \& Karanth, K.K. (2018) The production of humanwildlife conflict: a political animal geography of encounter. Geoforum: Journal of Physical, Human, and Regional Geosciences, 95, 153-164.

Meena, V., Jhala, Y.V., Chellam, R. \& Pathak, B. (2011) Implications of diet composition of Asiatic lions for their conservation. Journal of Zoology, 284, 60-67.

icmr (Ministry of Health \& Family Welfare, Department of Health Research, Indian Council of Medical RESEARCH) (2018) Update on Recent Lion Deaths in Gir forest. icmr. nic.in/sites/default/files/whats_new/Update-on-death-of-Gir-lionsOct-9-2018.pdf [accessed January 2020].

Miquelle, D.G., Smirnov, E.N., Quigley, H.G., Hornocker, M.G., Nikolaev, I.G. \& Matyshrin, E.N. (1996) Food habits of Amur tigers in Sikhote-Alin Zapovednik and the Russian far east, and implications for conservation. Journal of Wildlife Research, $1,138-147$.

Mizutani, F. (1999) Biomass density of wild and domestic herbivores and carrying capacity on a working ranch in Laikipia District, Kenya. African Journal of Ecology, 37, 226-240.

Mukenhirn, N. \& Eisenberg, J.F. (1973) Home ranges and predation in the Ceylon leopard. In The World's Cats. Vol. 1: Ecology and Conservation (ed. R.L. Eaton), pp. 142-175. World Wildlife Safari, Winston, USA.

Mukherjee, S. \& Mishra, C. (2001) Predation by leopard Panthera pardus in Majhatal Harsang Wildlife Sanctuary, W. Himalayas. Journal of the Bombay Natural History Society, 98, 267-268.

Mukherjee, S., Goyal, S.P. \& Chellam, R. (1994) Standardisation of scat analysis techniques for leopard (Panthera pardus) in Gir National Park, Western India. Mammalia, 58, 139-143.

Odden, M. \& WegGe, P. (2009) Kill rates and food consumption of leopards in Bardia National Park, Nepal. Acta Theriologica, 54, 23-30.

OLI, M.K. (1993) A key for the identification of the hair of mammals of a snow leopard (Panther uncia) habitat in Nepal. Journal of Zoology, London, 231, 71-93.

R Core Team (2013) R: A Language and Environment for Statistical Computing. R Foundation for Statistical Computing, Vienna, Austria.

Ramesh, T., Snehalatha, V., Sankar, K. \& Qureshi, Q. (2009) Food habits and prey selection of tiger and leopard in Mudumalai Tiger Reserve, Tamil Nadu, India. Scientific Transactions in Environment and Technovation, 2, 170-181.

ReECE, J.F. \& ChAWLA, S.K. (2006) Control of rabies in Jaipur, India, by the sterilisation and vaccination of neighbourhood dogs. The Veterinary Record, 159, 379-383.

Roelke-Parker, M.E., Munson, L., Packer, C., Kock, R., Cleaveland, S., Carpenter, M. et al. (1996) A canine distemper virus epidemic in Serengeti lions (Panthera leo). Nature, 379, 441-445.

SAnkar, K. \& Johnsingh, A.J.T. (2002) Food habits of tiger (Panthera tigris) and leopard (Panthera pardus) in Sariska Tiger Reserve, Rajasthan, India, as shown by scat analysis. Mammalia, $66,285-312$. 
Schaller, G.B. (1967) The Deer and the Tiger. University of Chicago Press, Chicago, USA.

Schaller, G.B. (1983) Mammals and their biomass on a Brazilian ranch. Arquivos de Zoologia, 31, 1-36.

Schwarz, S. \& Fischer, F. (2006) Feeding ecology of leopards (Panthera pardus) in the western Soutpansberg, Republic of South Africa, as revealed by scat analyses. Ecotropica, 12, 35-42.

Seidensticker, J.C. (1983) Predation of Panthera cats and measures of human influence in habitats of South Asian monkeys. International Journal of Primatology, 14, 323-326.

Seidensticker, J., Sunquist, M. \& McDougal, C. (1990) Leopards living at the edge of the Royal Chitwan National Park, Nepal. In Conservation in Developing Countries: Problems and Prospects (eds J.C. Daniel \& J.S. Serrao), pp. 415-423. Oxford University Press, Bombay, India.

Seimon, T.A., Miquelle, D.G., Chang, T.Y., Newton, A.L., Korotkova, I., Ivanchuk, G. et al. (2013) Canine distemper virus: an emerging disease in wild Endangered Amur tigers (Panthera tigris altaica). mBio, 4, eoo410-13.

Seligsohn, D. (2014) Dog bite incidence and associated risk factorsa cross-sectional study on school children in Tamil Nadu. BSc thesis. Swedish University of Agricultural Sciences, Uppsala, Sweden.

Shah, G.M., Jan, U., Bhat, B.A., Ahmad, F. \& Ahmad, J. (2009) Food habits of the leopard Panthera pardus in Dachigam National Park, Kashmir, India. Journal of Threatened Taxa, $1,184-185$.

Shehzad, W., Nawaz, M.A., Pompanon, F., Coissac, E., Riaz, T., Shah, S.A. \& TABERLET, P. (2015) Forest without prey: livestock sustain a leopard Panthera pardus population in Pakistan. Oryx, 49, 248-253.
Singh, P., Gopalaswamy, A.M. \& Karanth, K.U. (2010) Factors influencing densities of striped hyenas (Hyaena hyaena) in arid regions of India. Journal of Mammalogy, 91, 1152-1159.

SRINIVASAN, K. (2013) The biopolitics of animal being and welfare: dog control and care in the UK and India. Transactions of the Institute of British Geographers, 38, 106-119.

Taylor, L.H., Wallace, R.M., Balaram, D., Lindemayer, J.M., ECKery, D.C., Mutonono-Watkiss, B. et al. (2017) The role of dog population management in rabies elimination-a review of current approaches and future opportunities. Frontiers in Veterinary Medicine, 4, 1-15.

Tinari, K. (2008) Preliminary study on the diet composition of the leopard (Panthera pardus fusca) in Sanjay Gandhi National Park. Bombay Natural History Society, Mumbai, India.

Treves, A., Wallace, R.B., Naughton-Treves, L. \& Morales, A. (2006) Co-managing human wildlife conflicts: a review. Human Dimensions of Wildlife, 11, 383-396.

Wegge, P., Odden, M., Pokharel, C.P. \& Storaas, T. (2009) Predator-prey relationships and responses of ungulates and their predators to the establishment of protected areas: a case study of tigers, leopards and their prey in Bardia National Park, Nepal. Biological Conservation, 142, 189-202.

World Population Review (2020) worldpopulationreview.com/ world-cities/jaipur-population [accessed 19 June 2020].

Yirga, G., DeIongh, H.H., Leirs, H., Gebrihiwot, K., Deckers, J. \& BAUER, H. (2012) Adaptability of large carnivores to changing anthropogenic food sources: diet change of spotted hyena (Crocuta crocuta) during Christian fasting period in northern Ethiopia. Journal of Animal Ecology, 81, 1052-1055.

ZAR, J.H. (1996) Biostatistical Analysis. Prentice-Hall International, Englewood Cliffs, USA. 